\title{
Case Method Management
}

\author{
Harry W. Strachan \\ Professor Emeritus, INCAE, San Jose, Costa Rica
}

\author{
Harry.strachan@mesoamerica.com
}

\begin{abstract}
This article argues that superior executives often use case method teaching techniques as part of their management toolkit. It begins with a real life description ("Vern in Action") of a successful executive leading his subordinates on an important strategic issue. Some of the techniques which he deliberately uses with his subordinates are identified as those used by great case method teachers in their classrooms. The article even suggests that the case method can be a useful template for consulting via a "live case." Why case method techniques make for superior management provides insight on why case method teaching often leads to more effective learning in the classroom.
\end{abstract}

Keywords: case method, case studies

\section{Introduction}

I was exposed to "case method" teaching in both the Harvard Law School J.D. and the Harvard Business School Doctoral Program. However, it was really during my nine years of teaching in classrooms at the INCAE Business School and the Harvard Business School during the 1970s that I came to deeply appreciate and begin to understand the methodology. When I left my academic career to become a full time consultant with Bain \& Co, I gained an even deeper appreciation and understanding of why the principles underlying good case method teaching make for both superior managers and superior teachers.

Starting with a real life story of a manager, in this article, I advance the thesis that superior managers often use case method teaching techniques. Seeing why these techniques are superior in a business context helps us understand why students coming from a case method curriculum are likely to get superior training for real world management positions.

Also through my experience with "live cases," I argue that the structure of thinking embedded in the classic Harvard business case is an

Material published as part of this publication, either on-line or in print, is copyrighted by the Informing Science Institute. Permission to make digital or paper copy of part or all of these works for personal or classroom use is granted without fee provided that the copies are not made or distributed for profit or commercial advantage AND that copies 1) bear this notice in full and 2) give the full citation on the first page. It is permissible to abstract these works so long as credit is given. To copy in all other cases or to republish or to post on a server or to redistribute to lists requires specific permission and payment of a fee. Contact Publisher@InformingScience.org to request redistribution permission. efficient way of thinking through most business problems.

\section{Vern in Action}

One day around 1985, when I had left academia and was playing the role of consultant to business leaders with Bain $\& \mathrm{Co}$, I was sitting in on the weekly management meeting of a CEO client 
(let's call him Vern) that I greatly admired. Watching him in action, I noticed that a big part of his success as a manager was his use of case method techniques.

He sat at the head of the table. He had a carefully prepared agenda which this day included a tough strategy decision. He asked John, the involved division manager to introduce the issue and provide relevant background. He then went around the table asking each of his direct reports to provide input on the decision and say what they felt the company should do. These included Steve, head of production, Mark, head of marketing, Jim from HR and Jane, the CFO. He returned to John for his recommendation as he would be responsible for implementing the strategy.

When Mark asserted something about consumer preferences as part of his recommendation, Vern asked him, "How do you know that? What hard data do you have?"

When Jim simply repeated Steve's argument, Vern gently said, "Am I correct, you're just agreeing with Steve? If so, just say so and we'll move on."

John's recommendation at the end reflected the majority's conventional solution and was clearly different from Mark's more audacious approach. Vern, wishing to go deeper on the differences between these two options, asked each, "How would you go about implementing your solution?" He gave them time to debate their differences and amplify their arguments. This permitted the group to visualize more fully in time and space the two options. However Vern didn't let the discussion bog down, he kept pushing it forward.

At one point Vern brought the group up short by asking John, "What piece of evidence or analysis would cause you to agree with Mark?" A moment of silence followed. Each was forced to think about what data might cause them to change their opinion.

In this meeting Vern did not reveal his own thinking, although I knew he was drawn to Mark's more audacious solution. Instead he ended the meeting asking both Steve and Mark to use the two weeks before the group would meet again to do a piece of analysis both had agreed was important.

Two weeks later, with the new data and analysis, Steve and the others changed their mind and agreed on a version of Mark's more audacious recommendation. Vern closed the discussion saying "It looks like we all agree, let's do it."

\section{Good Case Method Teaching}

As I watched Vern in action, I suddenly thought He's doing what a good case method teacher does. Since I've seen Harvard business cases taught in a great variety of ways, some of which violate important principles of case method teaching, let me use Vern's actions to highlight some of the critical things good case method teachers do.

- Prior to the meeting Vern carefully prepared a complete analysis of his own. He didn't share this analysis, but it did permit him to spot omissions and ask good questions.

- He started the discussion by focusing on the end decision. He had John, the first speaker, summarize the key elements of the situation.

- He forced everyone at the table to get involved and put themselves in the shoes of the responsible manager, not just throw ideas into the discussion.

- He challenged Mark’s consumer assertions asking for data and analysis. 
- He cut short Jim's simple repetition in a respectful manner, but in a way that made it clear that valued contributions weren't repetitive or "bullshit."

- When an important aspect of the decision wasn't being addressed, for example implementation feasibility, he asked about it and made it an important part of the discussion.

- One of his questions, "What evidence would cause you to change your mind?" brought the group up short and forced them to think about something they'd never considered. He also allowed the meeting to sit in silence while each considered the question.

- He did not telegraph his own thinking early, and even in articulating the consensus, left everyone on the team owning the final decision. (I've noticed, when sitting in on some case method teachers, that they give students their own analysis, some even doing this via a power point presentation. Though they get positive reinforcement from giving students the "right answer," it's my considered opinion that this practice tends to sabotages the case method. It incorrectly suggests there is one right answer which is rarely the case. It stunts the muscle building by taking pressure off students to do heavy lifting in the analysis and decision making.)

- Finally, though not evident in my story above, let me mention one other thing which Vern did that is also the characteristic of great case method teachers. He was demanding of his people, but conveyed a deep faith in their capacity to meet his high standards. When he gave them negative feedback either on performance or effort, he still managed to inspire them. One of his direct reports told me, "Vern isn't fooled by my deficiencies though I try to hide them, but he makes me feel he sees gold in me that even I can't see."

\section{Why the Case Method Works}

It's not hard to see why executives reporting to a manager like Vern, make better decisions, implement them more effectively, get superior results, and also why they develop more rapidly. Many of these are also the reasons that students who are the product of a real case method curriculum tend in my experience at Bain and Mesoamerica Partners to do better in their first management or consulting positions.

1. The case method forces in-depth preparation and full participation.

2. The discussion process forces students or managers to expose their thinking to multiple viewpoints, the give and take of debate, the polish of data analysis, and considerations of implementation. Invariably the final decision reached is more thoughtful, more creative, more pragmatic than the first draft of a solution.

3. The managers feel responsible to make the decision successful. They are not tempted after the fact to say, "You know I never agreed with Vern's decision and sure enough it didn't work." In a similar fashion, when the sequel case B or C reveals flaws in a position the students took, they can't say, "You know that's pretty obvious, I thought of it." In the process they learn a useful humility about the difference between having a thought and taking a decision.

4. Finally, practice solving multiple problems, even those for which they are not directly responsible, helps both students and managers come down the "experience curve" much faster. By wearing Vern's shoes his managers get practice for the day when they will do 
his job. And a student who has wrestled with hundreds of business cases, leaves school with a base of experience it would take decades to acquire on the job.

\section{"Live Cases" as a Consulting Tool}

Leaving teaching for Bain consulting I found I had to put my teaching kit of skills to one side in order to learn Bain's way of consulting. Having however acquired the Bain skill set, I found there were some arrows from my teaching quiver that made me a more effective consultant. One of these was what I called doing a "live case" with potential or actual clients.

In a "live case" I gather clients and the consultants, with whom they might be working, in a room with whiteboards for a three or four hour session. With their help, we assemble the "case" in real time. Like a written Harvard cases, it begins with a quick summary of the perceived problems to solve or decisions to make and the situation. Then we work through relevant questions putting on the white board relevant data and analysis on the problem: the things they are already pretty sure they know, data they have already collected and analyzed. We also talk about what might be relevant but is not known, the holes in the data or analysis. We make a list of the principle options or solutions they are considering and some they may not have thought of. Our objective isn't to solve the problem but to organize a process that will ultimately meet their objectives, solve their problem and lead to actionable decisions.

What I have come to appreciate about this approach is that the live case not only helps me generate a more focused proposal and efficient work plan, but it also begins to create enthusiasm for the project, a sense of partnership, client confidence in the consultant who will be working with them as a result of the questions that suggest they have experience and expertise that might be relevant.

But the main reason I believe these "live cases" are successful is that they harness on behalf of clients an orderly way of thinking about business problems, one buried in the case method, which has repeatedly been proved valuable. Almost invariably at the end of one of these relatively short sessions, the client will say something like, "Thank you so much. You know, we've spent hours in our company discussing this issue. In today's session of just a few hours, we made more progress than in all those meeting. I already see things more clearly."

What the client is appreciating is the feeling that comes with going to the heart of a problem and organizing analysis in an orderly fashion. It is this capability which is so highly valued in a professional. "Good business judgment" is no doubt due to many things: intelligence, academic learning, and a lot of practical experience. However, in my opinion, few contribute more than absorbing the structure of analysis and decision making embedded in having to solve multiple business cases.

\section{Conclusion}

It's not a coincidence that Vern became famous for producing superior managers, who themselves went on to be successful "case method managers." And his example is one of the reasons I have come to feel that a similar case method teaching, when reproduced in the classroom, also creates superior managers. Part of the reason it works comes from the Socratic method of learning which underlies it. And part, I would argue, is the valuable structure of thinking embedded in most good cases. A very large part of it, though, comes from the muscle building, hard work solving multiple cases which is demanded by good case method teacher. 


\section{Biography}

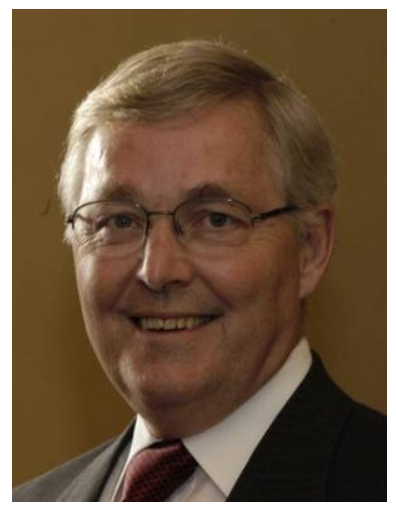

Harry Strachan is Managing Director of Mesoamerica Investments (1998-Present) whose divisions serve the major business groups of Mesoamerica from offices out of San Jose, Costa Rica and Bogota, Colombia. Mesoamerica Capital is involved in scale private equity investments. Mesoamerica Advisory provides strategy consulting and services on mergers and acquisitions. Mesoamerica Foundation channels part of the profits and our resources to support pro bono efforts mainly in the area of education.

Harry was a partner of Bain \& Co from 1979 to 1998 and continues Director Emeritus with Bain and Bain Capital in their new partner training and Mexico / C.A. activities.

Harry was a business school professor at INCAE (1970-1976), Associate Professor at the Harvard Business School (1976-1979) and Rector of INCAE in the 1981/2 Sandinista transition.

His education includes a B.A. from Wheaton College (1963), a J.D. from Harvard Law School (1966), and a D.B.A. from Harvard Business School (1972).

Harry was born in Costa Rica of missionary parents and today devotes a significant portion of his time to non-profit consulting and boards, to teaching and moderating with INCAE and Aspen Institute Programs. He is President of the Strachan Foundation he established in honor of his parents and grandparents. He is married, has two children and five grandsons. His hobbies are golf, poker and reading. 